Research.

\title{
INFLUENT OF FINANCIAL CAPITAL ON ITS RENTABILITY AT COOPERATIVE OWN BY THE EMPLOYEE OF THE CITY OF SUKABUMI (KPRI-PKS)
}

\author{
Nani Pujiastuti \\ Lecturer at Politeknik BBC, Sukabumi
}

\begin{abstract}
The study is carried out to understand the problems on the financial capital, its rentability, and the influent of rentability on the financial capital at the Cooperative Own by the Employee of the City of Sukabumi (KPRI-PKS). The method used in this study is a descriptive associative. This methode is used to provide solution to the question on casual's relation or influence of two variables. Correlation analysis technique, determination and regression is used. The data used in this study is the secondary data which was gathered from the financial report balance sheet and from the calculation net income (SHU) report. For collection of the data in this study is done through field research and literature survey. The study indicates, that the financial capital of KPRI-PKS from 2009-2013 is increased annually. The highest financial capital is reached in 2011 with total financial capital of IRD 757.982.120 and the lowest is in 2013 with the financial capital of IDR 368.134.591. The value of their capital rentability is fluctuated, but the trend is declining. The rentability value in 2009 could reach $15.70 \%$ and the lowest is in 2011 which is only 6.75\%. It is clearly showed the during 2009 to 2011 the rentability is drop significantly due to the increase of financial capital percentage compare to the increase of SHU percentage. While between 2012 and 2013 rentability of the financial capital is smaller and the percentage of SHU increased. Based on this study, the financial capital do positively influence the rentability up to $61 \%$ and the rest of $39 \%$ is influenced by other factors which are not included in this study.
\end{abstract}

Keywords : Financial capital, rentability.

\section{INTRODUCTION}

\section{Background}

Any business entity in running their business need capital. The capital can be selffunded or can be originated from the third party. Cooperative is one of the business entity with unique characters on its capital. The source of capital of cooperative is from the savings of the member both compoulsary and voluntary and others.

The structure of the capital is one of the factor which need attention to meet the need of the capital for the company. The structure of the capital could be the factor which directly affecting financial position of the company. One of the way to know the choice of the capital structure of the company if the company is able or not in maximizing the profit, return on financial capital may be used.

For internal control and for preparing better capital for providing better financial condition and prestige of the company, the manager use the analytical tools on financial report. This analysis strongly correlate to the need of management to effectively plan and to control the financial accuntability of the company. In regards to the financial efficiency and effectivity in relation to the achievement on interest, the rentability ratio is used. Rentability ratio is actually an indicator if the company gain the profit from the capital used. For this, the profit gain in certain period is compared with the capital used to obtain the profit during that period.

Nani Pujiastuti: Influent of Financial Capital on Its Rentability at Cooperative Own By The Employee of The City of Sukabumi (KPRI-PKS) 
I doing business, any business entity is aiming on producing the profit. So does the cooperative has the aim to produce SHU. For this reason, there is a need on skill to predict the cooperative in producing profit (SHU) from the capital used. The amount of capital used is very much affecting the profit gained. According to Amidipradja (2005:117): "any capital used in cooperative operational, the profit should be bigger." For this reason, the ability to predict in producing profit (SHU) from the capital used can be calculated from capital rentability ratio. Capital rentability according to Bambang Riyanto (2008:44) is the ratio between the available amount of profit for the owner of the capital in one side with the amount of capital which produced the profit itself one the other side.

According to theory above, fact can be seen on cooperative. Cooperative Own by the Employee of the City of Sukabumi (KPRI-PKS) is a cooperative with the main activity on saving-borrowing. The source of the capital of this cooperative is the financial capital and foreign capital. The financial capital is coming from compulsary saving, special saving of the member of cooperative, cooperative's reserve, donation and SHU. The capital from 2009 to 2013 increases annually. While capital rentability fluctuated with declining trend.

According to the above bacground, study is carried out to analyse this problem. The title of the study is "Influent of Financial Capital on Its Rentability at Cooperative Own by the Employee of the City of Sukabumi (KPRI-PKS)".

\section{Frame of thought}

Cooperative is doing business with initial capital originated from the compulsary saving of the cooperative's member. The structure of the capital is one of the factor which need attention to meet the need of the capital for the company. The structure of the capital could be the factor which directly affecting financial position of the company. The growth of the cooperative will affect the velue of the cooperative which can be seen from its performance in managing capital or from its financial position. One of the way to know the choice of the capital structure of the company if the company is able or not in maximizing the profit. Return on financial capital may be used as a tool by comparing its own capital to its rentability.

The amount of capital used is very much affecting the profit gained. According to Amidipradja (2005:117): "any capital used in cooperative operational, the profit should be bigger." For this reason, the ability to predict in producing profit (SHU) from the capital used can be calculated from capital rentability ratio. Capital rentability according to Bambang Riyanto (2008:44) is the ratio between the available amount of profit for the owner of the capital in one side with the amount of capital which produced the profit itself one the other side.

From the above theory, the size of SHU and financial capital can have an effect on rentability. This mean that if the financial capital increases, the rentablity will also increases. This will be happening when SHU also increases and the change of percentage lower than the percentage of the changing of the SHU increased.

According to explanation above, there is an influence of the financial capital on rentability which can be illustrated as following.

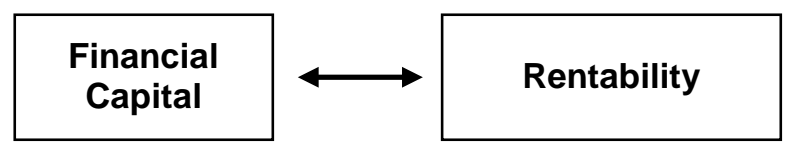

Figure 1: Frame of thought 


\section{Location and time of Research.}

To get the data and information required for writing this thesis, research carried out at Cooperative Own by the Employee of the City of Sukabumi (KPRI-PKS) located at Jalan Perpustakaan No.1 City of Sukabumi from April to August 2014.

\section{METHODOLOGY}

\section{Frame of Research and Hypothesis}

\section{Frame or Research}

Financial capital is one of the most important problem in running the business this is also true for cooperative. The avaibility of sufficient financial capital will be the most crucial factor to ensure smooth operation of cooperative business and the volume of the business if not the business activity will be slowed down. Protecting smooth operation of business activity could be a guaranty the growth and the development of the business could bring the profit to all of the member of the cooperative who provide financial capital to the cooperative and will bring the profit to the cooperative istself.

Basically, cooperative provides financial capital from their own and loan capital for running business. To know the effectivity of any business entity in managing financial capital required analysis which could illustrate its rentability ratio. Financial capital obtained by the company is used to develop is business which has to be maintained and accountable in transfarant manner.

Genarally, the change of financial capital rentability is influenced by several factors but in this research design, we would like to know the theirown capital rentability problem which is influenced by financial capital itself. The size of the financial capital will affect the rentability. This is due to the fact that its financial rentability is obtained from the calculation of profit ratio (SHU) from their own financial capital. When the capital increases, the rentability is also increases. This will be happening when SHU also increases and the percentage of the increase of the capital lower compared to the percentage of the increase of SHU. However, when their own capital increases but the rentability decreases due to the percentage of increase of financial more than the percentage of the increase of SHU. following:

Based on the explaination above, it can be illustrated on frame of research as

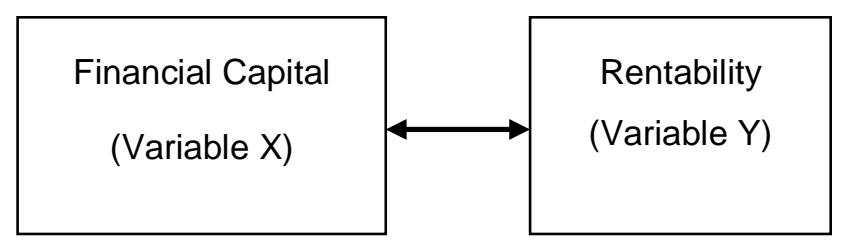

Figure 2 : Frame of Research

According to the research frame above, it is shown that there is casual interaction between variable $\mathrm{X}$ (independent) and variable $\mathrm{Y}$ (dependent).

\section{Research Methodology}

Method is a procedure or scientific method to know somethings. While research can be defined as a process of accumulating and analysing data systimatically and logically to reach certain aim. Conducting research means to gather data on the subject being observed accurately.

Nani Pujiastuti: Influent of Financial Capital on Its Rentability at Cooperative Own By The Employee of The City of Sukabumi (KPRI-PKS) 
Sugiyono (2012:2) defining research methodology as : "a scientific way to obtain data with the certain aim and certain purpose." This definition has several key words whis is scientific, data, aim and purpose.

1. Scientific way, that research is based on scientific characteristic which is rational empiris and systematics.

2. Data, in this research data is emperical data with the following criteria: valid and reliable.

3. The aim of research is certain and has a characteristic: finding, prove and development.

4. The purpose is that in this research through various testing which eventually can be used by certain party.

\section{Research design}

Research design is a structural and comprehenship frame work on the correlation among variables which are used as research materials.

In writing research report, it is necessary to search and collect appropriate data and information accurately on problem being investigated. This related to the aim to present the compilation of the complete data as the basis for research through the collection of data in detail from Cooperative Own by the Employee of the City of Sukabumi (KPRI-PKS) according to the identified problem to be solved. rentability.

Associated descriptive method is used to study the effect of financial capital on its

Descriptive according to Soejono and Abdurrahman (1999:23) is:

"a procedure to solve a problem being investigted by illustrating the condition of the research subject or object which could be a person, institution, society, and others at the present time according to the facts observe or fact as it is found naturally."

According to Sugiyono (2012:36) associative reseach is research having characteristics questioning the relationship of two variables or more. Associative method is a question on the relationship between two variables or more and forming casual relationship in the present of independent and dependent variables.

\section{Research variable and Operational variable}

\section{Research variable}

Sugiyono (2012:38) stated that research variable is things of any form which is being stipulated by researcher to be studied until the information on certain thing is obtained and eventually could be concluded. In this study, various variables tested are grouped as following:

1. Independent Variable $(X)$

Independent variable is a variable which influence another variable (dependent variable). In connection to the stipulated title, the independent variable is financial capital.

2. Dependent Variable $(\mathrm{Y})$

Dependent variables is a variable which influenced by other variable. In this study, dependent variable is the rentability of the financial capital.

\section{Operational Variable}

Research variable in this study consist of two variables namely variable $(X)$ or financial capital and variable $(Y)$ or its rentability. In this part, the definition of variable, dimention, indicator and research measurement scale used in this study at Cooperative Own by the Employee of the City of Sukabumi (KPRI-PKS) will be elaborated. 
According to the explanation of the above variables, the operational variable can be seen in Table presented here:

Table 1

Operational Variabel

\begin{tabular}{|c|c|c|c|c|}
\hline Variable & Definition & Dimention & Indicator & Scale \\
\hline $\begin{array}{l}\text { Variable } \\
(X) \\
\text { Financial } \\
\text { Capital }\end{array}$ & $\begin{array}{l}\text { Generally financial } \\
\text { capital is originated } \\
\text { from the owner of the } \\
\text { company which is } \\
\text { embaded in the } \\
\text { company for } \\
\text { uncertain time } \\
\text { (Bambang Riyanto, } \\
\text { 2008:240) }\end{array}$ & $\begin{array}{l}\text { The amount of } \\
\text { internal capital }\end{array}$ & 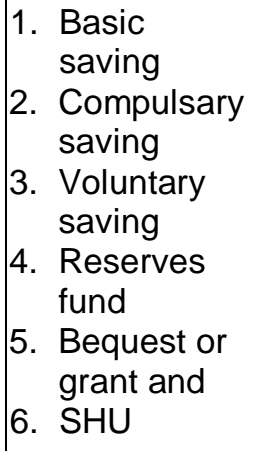 & Ratio \\
\hline $\begin{array}{l}\text { Variable } \\
(Y) \\
\text { Financial } \\
\text { capital } \\
\text { rentability }\end{array}$ & $\begin{array}{l}\text { Financial capital } \\
\text { rentability or } \\
\text { business rentability is } \\
\text { the comparison } \\
\text { between the amount } \\
\text { of the available profit } \\
\text { for the owner of the } \\
\text { capital in one hand } \\
\text { and the amount of } \\
\text { financial capital } \\
\text { producing profit on } \\
\text { the other hand } \\
\text { (Riyanto, 2008:44) }\end{array}$ & $\begin{array}{l}\text { 1. SHU after tax } \\
\text { 2. Amount of } \\
\text { financial capital }\end{array}$ & $\begin{array}{l}\text { Ratio between } \\
\text { profit (SHU) } \\
\text { and financial } \\
\text { capital }\end{array}$ & Ratio \\
\hline
\end{tabular}

\section{Research instrument}

Sugiyono (2011:110) stated that research instrument is a tool used to measure social natural phenomena observed. Specifically, all of the phenomena observed are actually research variable. Research instrument on the influence of financial capital at Cooperative Own by the Employee of the City of Sukabumi (KPRI-PKS) consist of:

\section{Instrument for data collection}

Instrument for data collection used in this study is a five year report $(2009-2013)$ on financial balance and the calculation of SHU obtain from Cooperative Own by the Employee of the City of Sukabumi (KPRI-PKS).

\section{Data collection procedure}

To obtain the required data accurately, various procedures are used which include:

1. Compiling secondary data and other data necessary related to the object of the study and the identified problem to be solved.

2. Analysing data available at the company relevant to the aim of the study. The data required for this study is financial report of the cooperative which include financial balance report and report of the profit (SHU) for five periods. For the additional data, observation is conducted by direct visit to the research object which followed by analysing data using data analysis technique. 
3. Literature study caonducted using books on general theory on releted issues and lectural notes related to the issues being studied.

4. Making final conclusion.

\section{Data Analysis Technique}

Data obtained from financial report will be analysied to calculate influence level of financial capital on its rentability. To provide answerd to the problem on how big the effect of financial capital on its rentability. Data analysis technique used is as following:

\section{Correlation Analysis}

Correlation analysis used to find if there is correlation between the two variables and if there is correlation, how strong. According to Dr. Suharsimi Arikunto (2006:270) the correlation coefficient is a statistical tool used to compare the measurement result of the two different variables so that we could determine the level of correlation among the two. Equation to calculate this according to Sugiyono (2008:248) is as following:

$$
\mathrm{r}=\frac{n \cdot \sum x \cdot y-\sum x \sum y}{\sqrt{n \sum x^{2}-\left(\sum x\right)^{2}\left(n \sum y^{2}-\left(\sum y\right)^{2}\right)}}
$$

Notes:

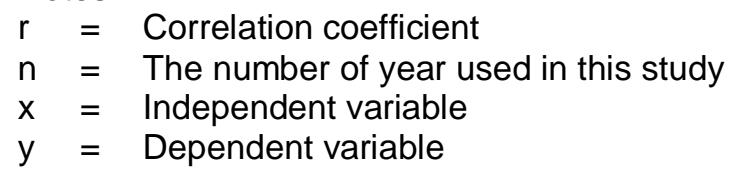

The explanation on the degree of cohesion between the two variables is based on interpretation of Sugiyono (2006:216) and can be classified as follow:

Table 2

Interpretation of correlation coefficent

\begin{tabular}{|c|c|c|}
\hline No & $\begin{array}{c}\text { Coefficient } \\
\text { Interval }\end{array}$ & Degree of Cohesion \\
\hline 1 & $0,00-0,19$ & Very low \\
\hline 2 & $0,20-0.39$ & Low \\
\hline 3 & $0,40-0,59$ & Moderate \\
\hline 4 & $0,60-0,79$ & Strong \\
\hline 5 & $0,80-1,00$ & Very Strong \\
\hline
\end{tabular}

Direction of correlation is illustrated by sign $(+)$ which show that there is paralel correlation, and if the sign is (-) indicating that there is paralel correlation with the opposite direction as mentioned by Suharsimi Arikunto, (2006:276):

Correlation + : The highest value of $X$ is, the highest value of $Y$. The increase value of $X$ is followed by the increase value of $Y$.

Correlation - : The highest value of $X$, the lowest value of $Y$ or the increase value of $X$ is followed by the decrease value of $Y$.

\section{Determination Analysis}

Determination analysis is used to know what is the precentage contributed by variable $X$ on fkuctuation value of variable $Y$. This analysis can be calculated using the following equation: 
$D=r^{2} \times 100 \%$

Note:

$\mathrm{D}=$ Determination coefficient

$r^{2}=$ Correlation coefficient (quadratic)

\section{Simple Linear Regression Analysis}

Regression analysis is a form of correlation among va. Its emphasis is on casual correlation. To calclate regression value, regression coefficient is used which is the unit size of variable $Y$ change caused by the change of variable $X$ in each unit. Regression used is simple linear regression. According to Riduwan (2005:244) simple regression is defined as following:

"The usefulness of simple regression test is to predict bounded variable ( $\mathrm{Y}$ ) when independent variable $(X)$ is known. Simple regression can be analysed based on functional correlation or casual correlation of independent variable (X) to the dependent variable (Y)".

$+b X$

Simple linear regression coefficient can be recognized from the equation $\hat{Y}=a$

$a=\frac{\left(\sum Y\right)\left(\sum X^{2}\right)-\left(\sum X\right)\left(\sum X Y\right)}{n \sum X^{2}-\left(\sum X\right)^{2}}$ $b=\frac{n \sum X Y-\left(\sum X\right)\left(\sum Y\right)}{n \sum X^{2}-\left(\sum X\right)^{2}}$

Note :

$\mathrm{n}=$ Nomber of years used in the study

$\mathrm{x}=$ Independent variable

y = Dependent variable

a $=$ Constant value

b = Regression coefficient direction

\section{RESULT}

\section{Financial Capital of KPRI-PKS}

Financial capital at KPRI-PKS is obtained from the saving of the member originated from basic saving, compulsary saving, special saving, stock, and donation. Financial capital during 5 year periods from 2009 to 2013 is illustrated in the following Table.

Table 3

Financial Capital of KPRI-PKS from 2009 to 2013

\begin{tabular}{|l|r|r|r|r|r|}
\hline \multirow{2}{*}{ Commentary } & \multicolumn{5}{|c|}{ Year } \\
\cline { 2 - 6 } & $\mathbf{2 0 0 9}$ & $\mathbf{2 0 1 0}$ & \multicolumn{1}{c|}{$\mathbf{2 0 1 1}$} & \multicolumn{1}{c|}{$\mathbf{2 0 1 2}$} & \multicolumn{1}{c|}{$\mathbf{2 0 1 3}$} \\
\hline Basic Saving & 150.495 .800 & 152.900 .000 & 150.370 .800 & 127.270 .800 & 593.623 .500 \\
\hline $\begin{array}{l}\text { Compulsary } \\
\text { Saving }\end{array}$ & 812.720 .586 & 1.096 .449 .035 & 1.339 .533 .791 & 1.650 .705 .453 & 1.344 .923 .853 \\
\hline Special Saving & 279.448 .625 & 506.109 .125 & 699.702 .375 & 860.706 .815 & 902.948 .425 \\
\hline Stock & 39.253 .119 & 120.616 .788 & 369.450 .102 & 458.557 .237 & 623.879 .117 \\
\hline Donation & 10.481 .494 & 10.481 .494 & 95.481 .494 & 85.481 .494 & 85.481 .494 \\
\hline Total Amount & $\mathbf{1 . 2 9 2 . 3 9 9 . 6 2 5}$ & $\mathbf{1 . 8 8 6 5 5 6 . 4 4 2}$ & $\mathbf{2 . 6 4 4 . 5 3 8 . 5 6 2}$ & $\mathbf{3 . 1 8 2 . 7 2 1 . 7 9 8}$ & $\mathbf{3 . 5 5 0 . 8 5 6 . 3 8 9}$ \\
\hline
\end{tabular}

Nani Pujiastuti: Influent of Financial Capital on Its Rentability at Cooperative Own By The Employee of The City of Sukabumi (KPRI-PKS) 
There is an increase of basic saving in 2009 and in 2010. This indicated that there is an increase in number of cooperative member. Basic saving, however is decrease in 2011 and in 2012 as the number of cooperative member is decreases. But the number of cooperative mamber in 2013 increases and consequently the basic saving of the cooperative again increases. Each year, compulsary saving steadly increases. This means that the discipline of the member of cooperative on monthly compulsary saving payment. Special saving by the member of cooperative increases each year which mean that large number of cooperative member who borrow the money from the cooperative. Stock of the cooperative increases every year. This stock is originated from SHU. Stock saving is maintained to improve financial capital of cooperative and for this reason, stock saving is not being used by the cooperative in running the business. Donation is obtained from individual or other institutions. Donation can be called as grant. Financial capital from donation or grant is not increased as the payment is uncertain.

In detail, the financial capital from 2009 to 2013 is depicted in the following Table and Figure:

Table 4

Up-down of the Amount and Percentage of Financial Capital of KPRI-PKS

\begin{tabular}{|c|c|c|c|c|}
\hline No & Year & Financial Capital & Up/Down & $\begin{array}{c}\text { Percentage } \\
\text { Up/Down }\end{array}$ \\
\hline 1 & 2009 & IDR 1,292,399,625 & & \\
\hline 2 & 2010 & IDR 1,886,556,442 & IDR 594,156,817 & 45.97 \\
\hline 3 & 2011 & IDR 2,644,538,562 & IDR 757,982,120 & 40.18 \\
\hline 4 & 2012 & IDR 3,182,721,798 & IDR 538182,236 & 20.35 \\
\hline 5 & 2013 & IDR 3,550,856,389 & IDR 368,134,591 & 11.57 \\
\hline
\end{tabular}

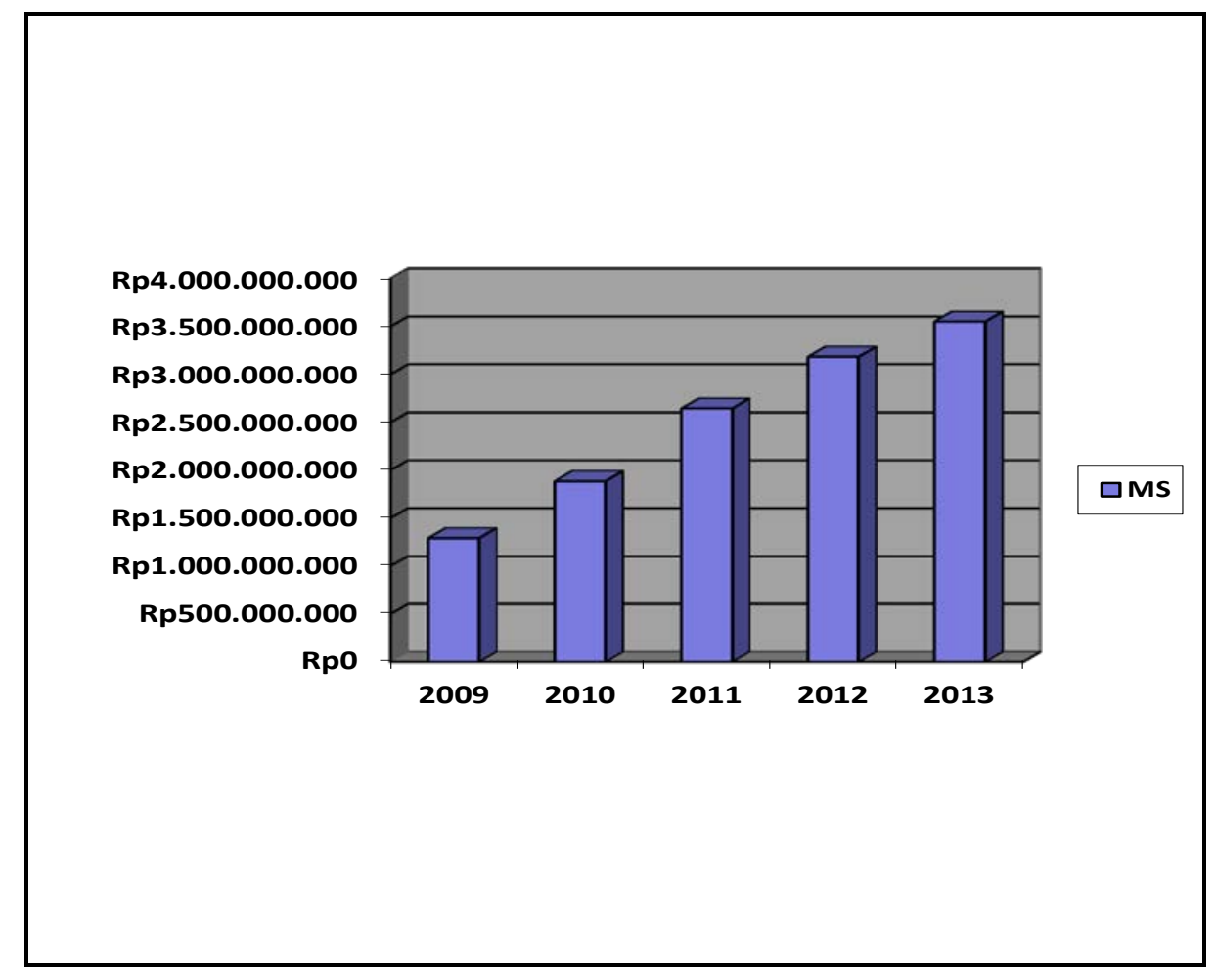

Figure 3

Graphical Change of the Financial Capital of KPRI-PKS Between 2009 and 2013

Nani Pujiastuti: Influent of Financial Capital on Its Rentability at Cooperative Own By The Employee of The City of Sukabumi (KPRI-PKS) 
According to the above Table and Graph, it is shown that finacial capital can be used to calculate its rentability. Financial capital increase each year. In 2009 the amount of financial capital is IRD 1,292,399,625 and in 2010 increases with the addition of IRD $594,156,817$ or increases by $45.97 \%$ to IRD $1,886,556,442$. In 2011 increases by the addition of IRD $757,982,120$ or increases by $40.18 \%$ to IRD 2,644,538,562. In 2012 increases by the addition of IRD $538,182,236$ or incrases by $20.35 \%$ to IRD $3,182,721,798$. In 2013 again increases by IRD $368,134,591$ or increases by $11.57 \%$ to IRD 3,550,856,389. In 2013 the percentage of increase is lower compare to that of happening in previous year.

\section{Rentability of Financial Capital of KPRI-PKS}

Rentability of the financial capital is a ratio between SHU gain to Financial capital. For this purpose, the data which has to be presented should inclued financial capital, SHU and its rentability. Prior to the calculation of financial capital, is necessary to present the data of SHU of the KPRI-PKS. The data of SHU of KPRI-PKS is the data from five years starting from 2009 to 2013. This data is illustrated in the following Tables.

Table 5

Data on Profit (SHU) of KPRI-PKS 2009-2013

\begin{tabular}{|c|c|c|c|c|}
\hline No & Year & Profit (SHU) & Up/Down & $\begin{array}{c}\text { Percentage } \\
\text { Up/Down }\end{array}$ \\
\hline 1 & 2009 & IDR 202,884,769 & & \\
\hline 2 & 2010 & IDR 231,460,756 & IDR 28,575,987 & $14.08 \%$ \\
\hline 3 & 2011 & IDR 178,653,828 & IDR 52,806,928 & $22.81 \%$ \\
\hline 4 & 2012 & IDR 224,102,087 & IDR 45,448,259 & $25.43 \%$ \\
\hline 5 & 2013 & IDR 353,865,190 & IDR 129,763,103 & $57.90 \%$ \\
\hline
\end{tabular}

Data on profit (SHU) at KPRI-PKS can be illustrated on the following Graph

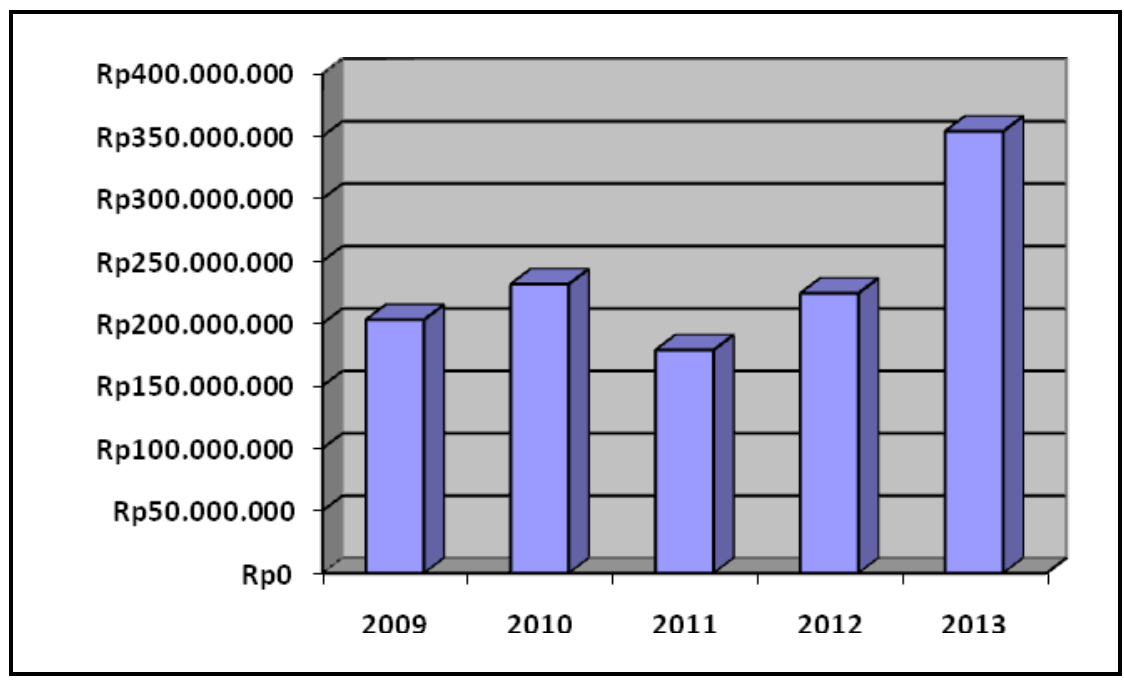

Figure 4

Graph Change of Profit (SHU) at KPRI-PKS 2009-2013

According to the above Table and Graphic, Cooperative gain profit fluctuatitatively every year. From 2009 to 2010 increases by $14.08 \%$, in 2011 decreases $22.81 \%$, in 2012 increasea by $25.43 \%$ and in 2013 again increases by $57.90 \%$. KPRI-PKS gain the highst

Nani Pujiastuti: Influent of Financial Capital on Its Rentability at Cooperative Own By The Employee of The City of Sukabumi (KPRI-PKS) 
profit (SHU) in 2013 which is IDR $353,865,190$ and the lowest SHU is in 2011 with the amount of IDR of $178,653,828$.

To know the value of financial capital rentability of the cooperative, the data of SHU above may help to obtain the value of financial capital rentablity which can be calculated using the equation as follow:

Financial capital rentability $=\frac{\mathrm{SHU}}{\text { Financial capital }} \times 100 \%$

From this data, the analysis of financial capital rentabiltity ratio during 5 year from 2009 to 2013 calculated as follow.

\section{Financial capital rentability in $\mathbf{2 0 0 9}$}

Financial capital rentability $=\frac{\operatorname{IDR} 202,884,769}{\operatorname{IDR} 1,292,399,625} \times 100 \%=15.70 \%$

\section{Financial Capital Rentability 2010}

Financial Capital Rentability $=\frac{\text { IDR } 231,460,756}{\operatorname{IDR} 1,886,556,442} \times 100 \%=12.27 \%$

\section{Financial Capital Rentability 2011}

Financial Capital Rentability $=\frac{\text { IDR } 178,653,828}{\operatorname{IDR} 2,644,538,562} \times 100 \%=6.75 \%$

\section{Financial Capital Rentability 2012}

Financial Capital Rentability $=\frac{\text { IDR } 224,102,087}{\operatorname{IDR} 3,182,721,798} \times 100 \%=7.04 \%$

\section{Financial Capital Rentability 2012}

Financial Capital Rentability $=\frac{\text { IDR } 353,865,190}{\operatorname{IDR} 3,550,856,389} \times 100 \%=9.96 \%$

From the calculation of the financial capital rentability, recapitulation made and depicted in the following Table.

Table 6

Recapitulation on the Percentage of Financial Capital Rentability, SHU, and Financial Capital

\begin{tabular}{|c|c|c|c|c|c|}
\hline No & Year & $\begin{array}{c}\text { Financial } \\
\text { Capital } \\
\text { Rentability }\end{array}$ & $\begin{array}{c}\text { Up/Down } \\
\text { of } \\
\text { Rentability }\end{array}$ & $\begin{array}{c}\text { Percentage } \\
\text { (Up/Down) of } \\
\text { SHU }\end{array}$ & $\begin{array}{c}\text { Percentage } \\
\text { (Up/Down) } \\
\text { Financial Capital }\end{array}$ \\
\hline 1 & 2009 & $15.70 \%$ & & & \\
\hline 2 & 2010 & $12.27 \%$ & Down & $14.08 \%$ & $45.97 \%$ \\
\hline 3 & 2011 & $6.75 \%$ & Down & $(22.81 \%)$ & $40.18 \%$ \\
\hline 4 & 2012 & $7.04 \%$ & Up & $25.43 \%$ & $20.35 \%$ \\
\hline 5 & 2013 & $9.96 \%$ & UP & $57.90 \%$ & $11.57 \%$ \\
\hline
\end{tabular}



Graph

Percentage Change on Financial Capital Rentability can be seen from the folloeing

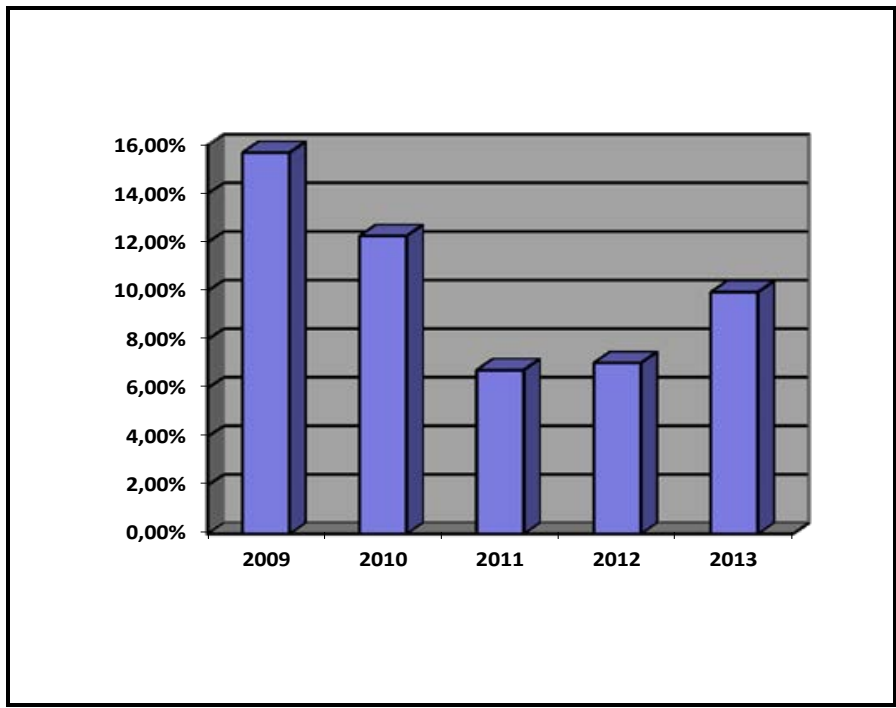

Figure 5

Graph on Ratio of Financial Capital Rentability 2009-2013

From the above Table and Graph, the financial capital rentability is fluctuated where in 2010 decreases fro, 15.70\% to 12.27\%, and in 2011 also decreases from $12.27 \%$ to $6.75 \%$, due to increase of the percentage of financial capital greater than the increase of SHU percentage where in 2010 the increase of financial capital is $45.97 \%$ while the increase of SHU is 14.08\% and in 2011 the increase of financial capital is $40.18 \%$ while SHU decrease by $22.81 \%$. In 2012 financial capital rentability increase from $6.75 \%$ to $7.04 \%$ and in 2013 inreases from $7.04 \%$ to $9.96 \%$, which is due to the change of precentage of the increase of financial capital lower than the percentage change of increase of SHU, where the percentage increase of financial capital in 2012 is 20.35\% and the percentage increase of SHU is $25.43 \%$, in 2013 the percentage increase of financial capital is $11.57 \%$ and the percentage increase of $\mathrm{SHU}$ is $57.90 \%$.

\section{Effect of Financial Capital on its Rentability at KPRI - PKS}

To know the effect of financial capital on its rentability, the following Table is presented as follow.

Table 7

The Amount of Financial Capital and Its Rentability

\begin{tabular}{|c|c|c|c|}
\hline No & Year & Financial Capital & $\begin{array}{c}\text { Financial Capital } \\
\text { Rentability }\end{array}$ \\
\hline 1 & 2009 & IRD 1,292,399,625 & $15.70 \%$ \\
\hline 2 & 2010 & IRD 1,886,556,442 & $12.27 \%$ \\
\hline 3 & 2011 & IRD 2,644,538,562 & $6.75 \%$ \\
\hline 4 & 2012 & IRD 3,182,721,798 & $7.04 \%$ \\
\hline 5 & 2013 & IRD 3,550,856,389 & $9.96 \%$ \\
\hline
\end{tabular}

Nani Pujiastuti: Influent of Financial Capital on Its Rentability at Cooperative Own By The Employee of The City of Sukabumi (KPRI-PKS) 
From the above Table, to provide answer to the question/problem, statistical analysis using SPSS verse 22 is carried out as following.

\section{Correlation Analysis}

Correlataion analysis is used to know the level of correlation among two or more variable(s). In this study, financial capital is $(X)$ and its rentability is $(Y)$. According to the computer program SPSS verse 22 , the coefficient regression obtained as depicted in the following table.

Tabel 8

Correlations

\begin{tabular}{|c|c|c|c|}
\hline & & Financial Capital & $\begin{array}{c}\text { Financial Capital } \\
\text { Rentability }\end{array}$ \\
\hline \multirow[t]{3}{*}{ Financial Capital } & $\begin{array}{l}\text { Pearson } \\
\text { Correlation }\end{array}$ & 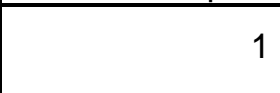 & \\
\hline & Sig. (2-tailed) & & .120 \\
\hline & $\mathrm{N}$ & 5 & 5 \\
\hline \multirow[t]{3}{*}{$\begin{array}{l}\text { Financial Capital } \\
\text { Rentability }\end{array}$} & $\begin{array}{l}\text { Pearson } \\
\text { Correlation }\end{array}$ & -.779 & 1 \\
\hline & Sig. (2-tailed) & .120 & \\
\hline & $\mathrm{N}$ & 5 & 5 \\
\hline
\end{tabular}

From this calculation, correlation between financial capital and its rentability is 0,779 . This figure indicating that there is a strong correlation in negative direction. This mean that if financial capital increase and other variable is constant, the rentability is down / decrease.

\section{Determination Coefficient}

The size of contribution of financial capital on its rentability can be calculated using determination coefficient where it is indicated by $\mathrm{R}$ Square or determination coefficient. Calculation using SPSS Verse 2.3, the value of -0.779 is obtained as depicted itn the following Table.

Tabel 9

Model Summary

\begin{tabular}{|l|c|r|r|r|r|}
\hline Model & $\mathrm{R}$ & $\mathrm{R}$ Square & $\begin{array}{c}\text { Adjusted R } \\
\text { Square }\end{array}$ & $\begin{array}{c}\text { Std. Error of the } \\
\text { Estimate }\end{array}$ & Durbin-Watson \\
\hline 1 & $.779^{\mathrm{a}}$ & .607 & .476 & .027 & 1.481 \\
\hline
\end{tabular}

a. Predictors: (Constant), Financial Caapital

b. Dependent Variable: Financial capital rentability

From this calculation, the $\mathrm{R}$ Square is $61 \%$. This mean that financial capital contribute around $61 \%$ and the rest of $39 \%$ is the contribution from other variable(s) which is not part of this study. 


\section{Regression Analysis}

Regression analysis is useful to know casual relationship among those two variables. Using SPSS verse 22 casual relationship among financial capital and its rentability can be seen on the folowing Tables.

Table 10

Coefficients

\begin{tabular}{|c|c|c|c|c|c|c|c|}
\hline \multirow[b]{2}{*}{ Model } & \multicolumn{2}{|c|}{$\begin{array}{l}\text { Unstandardized } \\
\text { Coefficients }\end{array}$} & \multirow{2}{*}{$\begin{array}{c}\begin{array}{c}\text { Standardized } \\
\text { Coefficients }\end{array} \\
\text { Beta }\end{array}$} & \multirow[b]{2}{*}{$\mathrm{t}$} & \multirow[b]{2}{*}{ Sig. } & \multicolumn{2}{|c|}{$\begin{array}{c}\text { Collinearity } \\
\text { Statistics }\end{array}$} \\
\hline & $\mathrm{B}$ & Std. Error & & & & Tolerance & VIF \\
\hline 1 (Constant) & .183 & .039 & & 4.710 & .018 & & \\
\hline $\begin{array}{l}\text { Financial } \\
\text { capital }\end{array}$ & $-3.161 E-11$ & .000 & -.779 & -2.153 & .120 & 1.000 & 1.000 \\
\hline
\end{tabular}

a. Dependent Variable: Financial capital rentability

Regression model for financial capital rentability is:

$Y=0,183-0,00000000003161(X)$

a. From this equation, regeression coefficient is 0,183 which mean that if there is no financial capital, its rentibility could reach up to 0,183 only.

b. Regression coefficient of $-3.161 \mathrm{E}-11 /-0,00000000003161$ explain that every increase of IDR 1 of the financial capital, there will be a decrease of its rentability of $0,000000003161 \%$ with the assumption that other variable stay constant.

\section{SUMMARY}

For this research discussion on the effect of financial capital on its rentability at KPRI-PKS), it can be concluded as follow:

1. Financial capital at KPRI-PKS from 2009 to 2013 increase every year where the highest increse occure in 2011 with the amount of IRD 757,982,120 and the lowest is in 2013 with the amount of IRD 368,134,591.

2. Financial capital rentability of KPRI-PKS fluctuate but the trend is decreasing. The highest rentability is achieved in 2009 with the percentage of $15.70 \%$ and the lowest is happening in 2011 which is only $6.75 \%$. From 2009 to 2011 it contued decrease, while in 2012 and 2013 increases due to the change of ercentage of the increase of financial capital lower compare to the increase of percentage of the increases of SHU.

3. The effect of financial capital $(X)$ on its rentability $(Y)$ is $61 \%$ and the rest of $39 \%$ is due to other factor(s) which is not part of this study.

\section{REFERENCE}

Anwari Achmad, Mulyo Praptowo (1983), Kredit Kelayakan. Jakarta,

Hery, S.E., M.Si. 2013. Akuntansi Dasar 1 \& 2. Jakarta: PT.Grasindo.

Ikatan Akuntan Indonesia. 2008. Standar Akuntansi Keuangan. Jakarta: Salemba Empat.

Keputusan Menteri Negara Koperasi Usaha Kecil dan Menengah Republik Indonesia No: 91/Kep./M.UKM/IX/2004

Nani Pujiastuti: Influent of Financial Capital on Its Rentability at Cooperative Own By The Employee of The City of Sukabumi (KPRI-PKS) 
The Accounting Journal of BINANIAGA Vol. 02, No. 01, 2017

PISSN: $2527-4309$

EISSN: $2580-1481$

M.Rachmat Firdaus, (1985), Teori dan Analisa Kredit serta Ketentuan-Ketentuan tentang Kredit.

Munawir. 2004. Analisa Laporan Keuangan. Edisi Keempat, Yogyakarta: Liberty

Sugiyono, Metode Penelitian Bisnis, (Bandung : CV Alfabeta,2006).

Undang-Undang Perkoperasian. 2012. Bandung: Fokusmedia

Nani Pujiastuti: Influent of Financial Capital on Its Rentability at Cooperative Own By The Employee of The City of Sukabumi (KPRI-PKS)

Page : 86 